\title{
The Effect of Foster Care and Self-Efficacy on the Physical Activities of Elementary School Students
}

\author{
Samsudin $^{1}$, Ali Maksum², Anung Priambodo ${ }^{3}$ \\ ${ }_{1,2,3}$ Postgraduate Program in Sports Education Department, Universitas Negeri Surabaya, Indonesia \\ Samsudin2829@gmail.com
}

\section{Abstract}

Parenting is a process of interaction between parents and children in educating, guiding, and directing the development of children's personalities. Parenting patterns play an important role in the formation of children's self-efficacy to behave independently and always strive in the face of every difficulty. This study aims to examine the influence of foster care patterns and self-efficacy on physical activity. The subject of this study was grade 6 students of SD Islam Raden Paku Surabaya as many as 70 students consisting of 40 male students and 30 female students. The data was collected using questionnaires and analyzed using multiple regressions. The results showed that the pattern of foster care and self-efficacy together significantly influenced the physical activity of elementary school students in grade VI, with a score of $F$ of 3,765 at a significance of 0.005 . Authoritarian parenting patterns significantly influenced the physical activity of students with a beta score of 0.259 at a significance of 0.027, while the other three foster patterns had no significant effect. Self-efficacy significantly influenced the physical activity of students with a beta score of 0.458 at a significance of 0.001 .
Keywords parenting patterns; self efficacy; physical activity

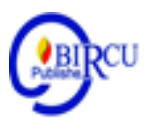

\section{Introduction}

Physical activity is a movement that is carried out in a planned manner as a form of muscle training and energy burning. In this case all body movements that include various sports both in competition and just filling leisure time or hobbies that can be done in everyday time. Whereas according to explaining that physical activity is a state of the body in experiencing minimal movement and energy does not require much in the process of burning in other words resting metabolic retest.

Technological advances have a tremendous impact on people's lives, especially on the advancement of information and communication technology in the form of communication aids, one of which is gadgets with the presence of gadgets all physical activities of the community that should be able to be done as a means to provide sufficiency in exercise, slightly reduced so that it affects health with many emerging diseases such as chronic heart disease, kidney failure and overweight. In every innovation is created to provide positive benefits for human life itself. Technology also provides many conveniences, as well as many technological innovations that have been enjoyed in recent years. But on the other hand the development of technology causes complex negative effects beyond the benefits of the technology itself

From the above thinking is very contrary to the goal of obtaining an optimal physical condition or health, people should try to implement a healthy lifestyle by not relying on technological advances excessively. But the character of the Indonesian people itself 
considers that physical activity is a daily activity that has been done so that in leisure time is more used to relax with mambaca newspapers, see television, play gadgets and various other activities that seem not to exess much energy. One form of technological progress and development today is the gadget

From the results of basic Health Research 2013 (RISKESDAS 2013) shows that in Indonesia, the population at the age of $\geq 10$ years who are classified as lacking physical activity by $26.1 \%$. In this case, the age group between 10-14 years has a passive lifestyle with a percentage of $67 \%$,

While in adolescence and adults in the age of 15-24 years has a percentage of $52 \%$. Of the 22 provinces with exceeding numbers are DKI Jakarta province in the fifth highest position with a percentage of $44.2 \%$, Papua with a percentage of $38.9 \%$, and West Papua with a percentage of $37.8 \%$, southeast Sulawesi and Aceh all have a percentage of $37.2 \%$. For the special region of Yogyakarta and the provinces of the population who do physical activity is less active or passive by $20.8 \%$.

In this case with the increasing complexity of problems in life one of them is VUCA (volatility, uncertainly, complexity, and ambiguity). In recent times much talked about in the world, not only that there are several other factors such as biological, psychological and social factors that occur so that the increase in the number of people with psychiatric disorders will burden the state's finances and imply a decrease in productivity in the long term (Infallible, 2018).

In the mindset of Indonesian people that the importance of a healthy lifestyle is still likely to be ignored. They consider that behaving in a healthy lifestyle they have done in their daily lives, but the fact is still not. Whereas with a healthy lifestyle.

Will form a good behavior as an effort to maintain the condition of the body to always be in a healthy and fit state. Environmental factors greatly affect especially in the family environment. The role of parents as educators is first in the family before the child gets an education in a formal place such as in school.

The role of parents as educators provides a good example so that it is exemplary by the child, so the pattern of foster care is the best way that parents can do to educate and train their parents as an obligation that must be met by parents before the child gets a formal education. In terms of the role of foster care patterns plays an important role in giving influence to the personality and adequacy of children's movements to always live healthy and active.

While in a formal environment such as in school children-will brings parenting patterns as has been taught in the family. In formal education or school children usually do physical activities during physical education learning, after which students spend their free time playing, buying food and relaxing in class. With the role of parenting patterns, parents get used to doing an activity such as physical activity as an education from the family environment. So in this case the family has a big impact on the mindset or self-efficacy of physical activity in the child, especially in obtaining a goal to be achieved.

If in the behavior of daily life the role of parents and schools can apply healthy lifestyle behaviors to children then without any encouragement or coercion they will do so with the awareness of the heart without pressure or coercion as an effort to realize that the importance of maintaining a healthy lifestyle. In this case the role of parents is very important because there are many problems that occur because of the lack of precisely the parenting pattern given to the child so that it forms the personality of the child becomes ungood. Like only parents give gadgets to children after school as a means of playing children to always stay at home and reduce boredom after learning at school. But parents 
seem to overdo it in children without restrictions on the use of gadgets, so that children are accustomed to playing gadgets without realizing their socialization activities and physical movements are reduced.

In overcoming these problems, the importance of parenting patterns as the basis in education is non-formal in order to teach that the importance of a healthy lifestyle that will later form personality or self-efficacy in children. Self-efficacy is a belief that a person has towards one's own ability to solve tasks and problems experienced as a determinant of a person in feeling something, thinking logically and motivating one's self in behaving.

In this case the planting of a healthy lifestyle in the family environment and school environment should be instilled as early as possible so that in the future it will be able to form good self-efficacy in accordance with the parenting pattern.

\section{Research Methods}

The type of research used is quantitative research using non-experimental methods, as explained by Maksum (2018) that "non-experimental research is a research in which research has absolutely no opportunity in providing treatment in managing data on variables that may play a role in the appearance of a symptom, because in the observed symptoms there has been expost facto".

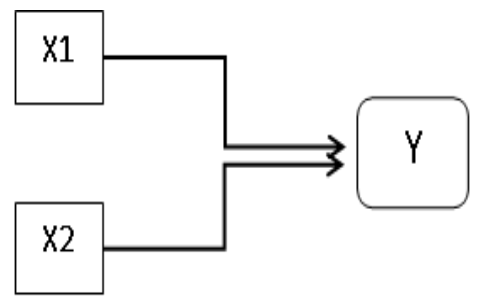

Figure 1. Research Design

Source: (in comsumers Maksum, 2018

Description:

$\mathrm{X}_{1} \quad$ : Prediktor 1 (Foster Care Patterns)

$\mathrm{X}_{2} \quad$ : Prediktor 2 (Self-Efficacy)

Y : Kriterium (Physical Activity of Grade 6 Student:

Operational definition is a research variable that is intended to understand the meaning in each research variable before analysis (Sujarweni, 2014). So in this study there are three variables, namely two independent variables and one dependent variable as the researchers described as follows:

1. Parenting Patterns $\left(\mathrm{X}_{1}\right)$

Foster care is a process of interaction between parents and children, which includes activities such as nurturing, educating, guiding and disciplining in obtaining the process of maturity either directly or indirectly.

2. Self Efficacy (self efficacy) $\left(\mathrm{X}_{2}\right)$

Perceived self-efficacy relates to a person's belief in the ability to produce given pencapain (Bandura, 1997). 


\section{Physical Activity (Y)}

Physical activity is a physical movement both walking, running, lifting weights aimed at strengthening muscles (exercise). Whereas according to who physical activity (PA) is a motion produced by muscles to produce movement and require energy in the process.

The variables studied in this study were the influence of parental care patterns (X1) and self-efficacy (X2) on students' physical activity (Y). In this study took samples from a population by using questionnaires as the main tool in collecting data. In addition, survey research based on logic thinking that uses theories as the basis of thought in research. Population is a universe that means the universe or the whole of the research subjects whose characteristics have been determined by researchers. Populations can be people, events, or other subjects whose characteristics have been identified and determined to be assigned to research subjects (Sriundy, 2015).

The population in this study is all elementary school students in east Surabaya area. In this study, the research sampled 70 students from grade 6 at SD Islam Raden Paku Surabaya. Data collection techniques using questionnaires or questionnaires given online are compiled using google forms that are given directly to students and parents as respondents. Questionnaire measurement scale using likert scale. Before the questionnaire was used in the research conducted a test of the validity and reliability of each instrument. To test validity using Product Moment, while reliability test using Cronbach's Alpha formula

Before performing multiple regression analysis, data prerequisite test will be done with classic assumption test which includes normality test, linearity test, multicollinierity test and homoskedastisity test. In the data analysis used in this study directly using multiple regression analysis techniques with the help of computer computer programs SPSS (Statistical Program for Social Science) 23.0. Multiple regression analyses were used to prove the extent to which the influence of foster care patterns and self-efficacy together had an effect on students' physical activity and which parenting patterns effectively influenced the physical activity of elementary school students.

\subsection{Hypothetical Test Terms}

Before conducting hypothesis testing, especially the use of parametric statistics is usually done asusmsi testing. In the prerequisite data in this study used 4 tests that include normality test, linearity test, multicollinierity and homoskedastisity test.

\section{a. Normality Test}

Normality test aims to ensure the data obtained is symmetrical or normal distribution, i.e. the distribution of numbers is mostly in the middle, and the more to the right or left, the distribution of numbers will be smaller so that it resembles a bell or curve. Testing normality of the data could use Kolmogorof-Smirnov and Shapiro-Wilks. In the normality test, the provision applies if the p-value is greater than 0.05 then the data is said to be normal but if otherwise the $\mathrm{p}$-value is smaller compared to 0.05 , the data is declared not to be normally distributed. 
Table 1. Normality Test Results

\begin{tabular}{|c|c|c|c|c|c|c|}
\hline \multicolumn{7}{|c|}{ Tests of Normality } \\
\hline & \multicolumn{3}{|c|}{ Kolmogorov-Smirnov } & \multicolumn{3}{|c|}{ Shapiro-Wilk } \\
\hline & Statistic & df & Sig. & Statistic & df & Sig. \\
\hline PHYS ICAL ACTIVITY & .091 & 70 & $200^{\circ}$ & .847 & 70 & .000 \\
\hline PARENT PATTERN (X1) & .093 & 70 & $200^{\circ}$ & .979 & 70 & 277 \\
\hline SELF EFFICATION (X2) & .087 & 70 & $200^{\circ}$ & .969 & 70 & .083 \\
\hline \multicolumn{7}{|c|}{$\because$ This is a lower bound of the true significance. } \\
\hline
\end{tabular}

From the output normality of data using SPSS in table 4.2 obtained signifiksan value (Asymp. Sig 2-tailed) for variable $\mathrm{X} 1$ is 0.200 variable $\mathrm{X} 2$ is 0.200 and variable $\mathrm{Y}$ is 0.200

Decision: Data is distributed normally because of significant values (Asymp. The 2-tailed sig) for each variable is greater than 0.05 which means the $\mathrm{X} 1 \mathrm{X} 2$ and $\mathrm{Y}$ variables are normally distributed. So that the assumption of normality is met and regression analysis techniques can be used.

\section{b. Linearity Test}

Linearity test aims as an effort to ensure data is linear from existing data distribution. Linearity testing is needed in regression analysis or causal correlation. In the linearity test the provision applies if the price of $\mathrm{F}$ is not significant or greater than 0.05 then the relationship between predictor and cryptium is declared linear and vice versa if the price of $\mathrm{F}$ is significant or less than 0.05 then the relationship between predictor and cryptium is declared not linear.

Table 2. Results of the Linearity Test of Variable $\mathrm{Y}$ with $\mathrm{X}_{1}$

\begin{tabular}{|c|c|c|c|c|c|c|c|}
\hline \multicolumn{8}{|c|}{ ANOVA Table } \\
\hline & & & $\begin{array}{l}\text { Sum of } \\
\text { Squares }\end{array}$ & df & $\begin{array}{l}\text { Mean } \\
\text { Square }\end{array}$ & $\mathrm{F}$ & Sig. \\
\hline ACTIVITY & Between & (Combined) & 6538.719 & 29 & 225.473 & .790 & .743 \\
\hline PHYSICAL (Y) & Groups & Linearity & 2.879 & 1 & 2.879 & .010 & .920 \\
\hline $\begin{array}{l}\text { PATTERN } \\
\text { CARE(X1) }\end{array}$ & & $\begin{array}{l}\text { Deviation from } \\
\text { Linearity }\end{array}$ & 6535.840 & 28 & 233.423 & .818 & .708 \\
\hline & \multicolumn{2}{|c|}{ Within Groups } & 11412.367 & 40 & 285.309 & & \\
\hline & \multicolumn{2}{|l|}{ Total } & 17951.086 & 69 & & & \\
\hline
\end{tabular}

Linearity test results based on data contained in table 4.3 above showed that the regression line of foster pattern variable (X1) with physical activity (Y) in deviation from linearity is 0.818 and significant value of $0.708>0.05$ thus between physical activity variable (Y) has a linear relationship with foster pattern (X1). 
Table 3. Results of the Linearity Test of Variable $\mathrm{Y}$ with $\mathrm{X}_{1}$

\begin{tabular}{|c|c|c|c|c|c|c|c|}
\hline \multicolumn{8}{|c|}{ ANOVA Table } \\
\hline & & & $\begin{array}{l}\text { Sum of } \\
\text { Squares }\end{array}$ & df & $\begin{array}{l}\text { Mean } \\
\text { Square }\end{array}$ & $\mathrm{F}$ & Sig. \\
\hline ACTIVITY & Between & (Combined) & 6538.719 & 29 & 225.473 & .790 & .743 \\
\hline PHYSICAL (Y) & Groups & Linearity & 2.879 & 1 & 2.879 & .010 & .920 \\
\hline $\begin{array}{l}\text { PATTERN } \\
\text { CARE(X1) }\end{array}$ & & $\begin{array}{l}\text { Deviation from } \\
\text { Linearity }\end{array}$ & 6535.840 & 28 & 233.423 & .818 & .708 \\
\hline & \multicolumn{2}{|l|}{ Within Groups } & 11412.367 & 40 & 285.309 & & \\
\hline & \multicolumn{2}{|l|}{ Total } & 17951.086 & 69 & & & \\
\hline
\end{tabular}

Linearity test results based on data contained in Table 4.8 above showed that the regression line of self-efficacy variable (X2) with physical activity (Y) deviation from linearity is 2,493 and a significant value of $0.004<0.05$ thus between the variables of physical activity (Y) does not have a linear relationship with self-efficacy (X2).

\section{c. Multicollinierity Test}

In mutikolinieritas test can be known test that can detect in test equations made to know the symptoms of multicollinierity by using auto correlation among free variables. That is by looking at each variable relationship is free against other free variables, by looking at the table of coefficients of correlation coefficient. The method for testing the existence of multi-covariability is seen in the Variance Inflations Factor (VIF). The limit of vif is $<10$.

Table 4. Multicollinearity Test Results

\begin{tabular}{|c|c|c|c|c|c|c|c|c|}
\hline \multicolumn{9}{|c|}{ Coefficients } \\
\hline & \multirow[t]{2}{*}{ Model } & \multicolumn{2}{|c|}{$\begin{array}{l}\text { Unstandardized } \\
\text { Coefficients }\end{array}$} & \multirow{2}{*}{$\begin{array}{c}\begin{array}{c}\text { Standardized } \\
\text { Coefficients }\end{array} \\
\text { Beta } \\
\end{array}$} & \multirow[t]{2}{*}{$\mathrm{t}$} & \multirow[t]{2}{*}{ Sig. } & \multicolumn{2}{|c|}{$\begin{array}{l}\text { Collinearity } \\
\text { Statistics }\end{array}$} \\
\hline & & $\mathrm{B}$ & Std. Error & & & & Tolerance & VIF \\
\hline \multirow[t]{4}{*}{1} & (Constant) & 42.161 & 16.161 & & 2.609 & .011 & & \\
\hline & PARENT & & & & & 338 & & 1.10 \\
\hline & $\begin{array}{l}\text { PATTERN (X1) } \\
\text { SELF }\end{array}$ & -.181 & .187 & -.114 & -.965 & .338 & .905 & \\
\hline & $\begin{array}{l}\text { EFFICATION } \\
\text { (X2) }\end{array}$ & .815 & .234 & .411 & 3.481 & .001 & .905 & $\begin{array}{r}1.10 \\
5\end{array}$ \\
\hline
\end{tabular}

a. Dependent Variable: AKTIFITAS FISIK (Y)

Based on Table 4.5 obtained multicollinierity test results with variable tolerance value X1 of $0.905>0.10$ and VIF value of $1.105<10$, and the value of vareabel X2 tolransi of $0.905>0.10$ and VIF value of $1.105<10$, therefore from the above results taken the decision that there is no multicollitas of each independent variable in the regression model. Due to the value of the tolerance is greater than 0.10 and the VIF value is more than 10.00. So estimation is considered efficient if it has a minimum variant and the fault variant is constant. Thus the assumption of homoskedastisitas can be fulfilled (Maksum, 2018b). Tolerance is greater than 0.10 and the VIF value is less than 10.00 . Then the estimate is considered efficient if it has a minimum variant and the error variance is constant. Thus the homoscedasticity assumption can be fulfilled (Maksum, 2018b). 


\section{d. Homoskedastisity Test}

In the homoskedastisity test aims as an attempt to test errors in statistical models, especially on regression analysis whether there are variants of errors affected by other factors or not. Homoskedastisity conditions that reflect residual value variation1 in each predicted value are constantly indispensable. on the contrary, we do not want the data condition to be heterosesedastiity because it can lead to inefficient parameter estimation resulting in large variants.

Table 5. Homoscedasticity Test Results

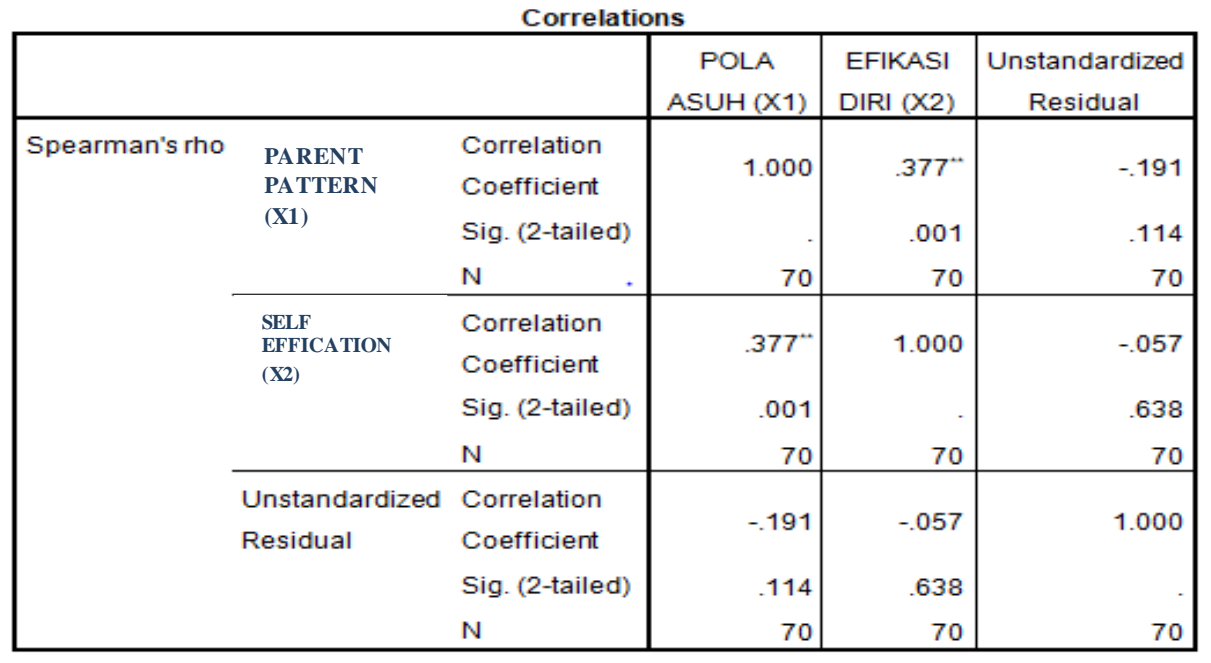

**. Correlation is significant at the 0.01 level (2-tailed).

From the results of the analysis of homoskedastisity test in Table 4.6 it is explained that all predictors with residual value of $>0.05$ can be said that the regression model obtained is homoskedastisitas. The value of 2-tailed X1 significance is 0.114 , and X2 is $0.638>$ from 0.05 . So in this case it can be concluded that the residual variant of this regression model is homoskedastisitas, so that regression analysis can be done.

\section{Discussion}

Based on the results of data analysis in the research of Foster Care Pattern (X1) and Self Efficacy (X2) on Fsik Activities of elementary school students (Y) obtained the following data; The pattern of foster care and self-efficacy together significantly influenced the physical activity of elementary school students in grade VI, with an F grade of 3,765 at a significance of 0.005 . Authoritarian parenting patterns significantly influenced the physical activity of students with a beta score of 0.259 at a significance of 0.027, while the other three foster patterns had no significant effect. Self-efficacy significantly influenced the physical activity of students with a beta score of 0.458 at a significance of 0.001 .

\subsection{Multiple Regression Analysis}

Regression analysis is used to determine the extent to which the influence of foster care patterns and self-efficacy simultaneously affects the physical activity of grade 6 students at Raden Paku Islamic Elementary School Surabaya. So the results of multiple linear regression are as follows 
Tabel 6. Multiple Regression Analysis

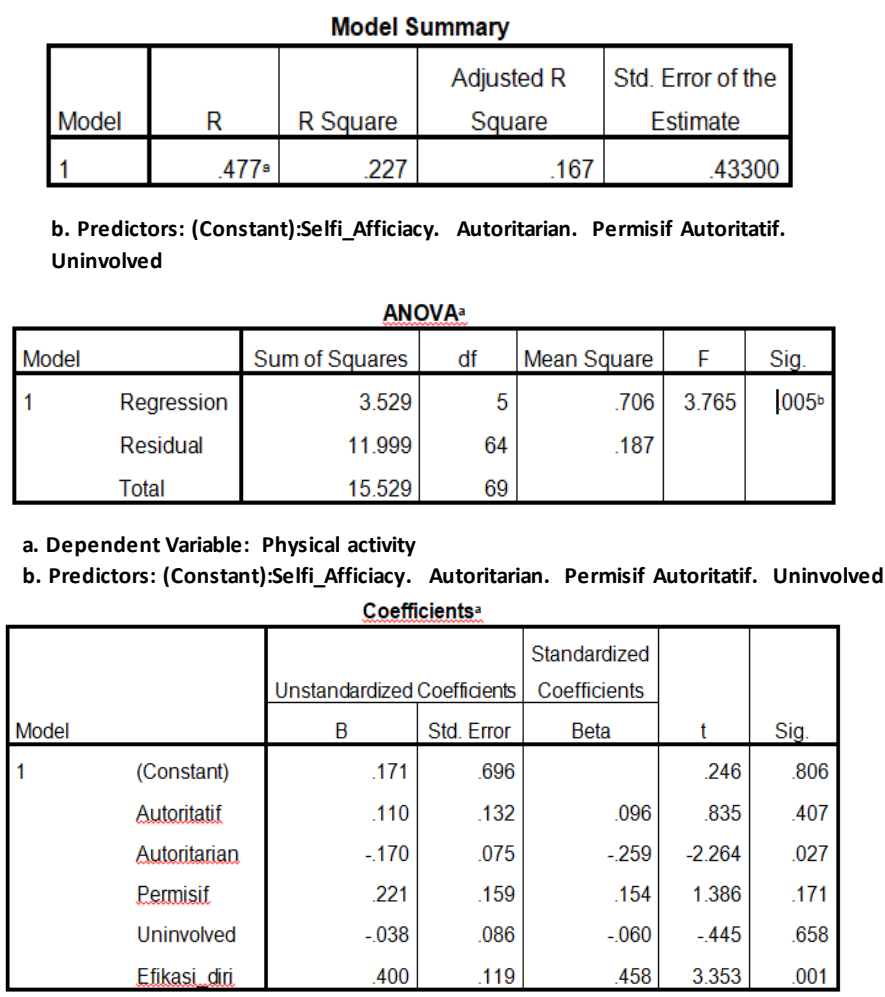

a. Dependent Variable: Physical activity

Based on the results of the analysis in the table above, it is interpreted that the correlation between predictor variable 1 (Foster Pattern) and predoctor 2 (Self Efficacy) to cryptium (Physical Activity) is 0.477 . From the regression analysis that has been done it appears that the price of $\mathrm{F}$ is 3,765 at a significance of 0.005 . Correlation between predictor 1 (Foster Pattern) has 4 types of each, namely; with authoritative foster care pattern type against physical activity of 0.96 , in authoritarian foster care pattern type against physical activity of -0.259 , in permissive foster pattern type against physical activity of 0.154 and in uninvolved foster care pattern type of physical activity is 0.86 and the correlation between predictor 2 (self-efficacy) to cryptium (physical activity) of 0.458 . With this data at the same time corroborate the opinion that the strength of bivariate relationships, one free variable and one bound variable, will be weakened when included the next free variable. In the case of the above relationship between self-efficacy of 0.477 but after inserting other free variables in the form of foster care patterns, the correlation of the two weakened to 0.458 .

Parenting patterns have a considerable important role in shaping children's behavior and independence. Parents have the role of nurturing, guiding, helping and directing children to become more independent. In this case in accordance with the opinion of (Sari, 2018) Parenting pattern is a factor that can affect the independence of student learning because of the family environment in which there are parents who play a full role and provide an early education before attending a formal education that is before the child enters a school, the child has received an education from his parents.

As a result of the study seen from representative foster care patterns obtained by each student is different but from the results of the analysis more dominant students obtained a type of authoritarian foster care pattern. Authoritarian parenting patterns significantly influenced the physical activity of students with a beta score of 0.259 at a 
significance of 0.027 , while the other three foster patterns had no significant effect. so in this case parents tend to give restrictions and encourage the child to follow all directions from the parents. Authoritarian parents establish strict control and give the child less opportunity to communicate verbally, so authoritarian parents are in complete control of controlling and supervising their children. In this parenting pattern, parents try to shape the character and evaluate the child's attitudes and behaviors in accordance with the standards set. Children who get treatment for authoritarian parenting often seem less happy, frightened, and feel minded in every thing and have weak communication and difficulty in expression. Authoritarian parents are trying to shape their children with binding rules. In this case parents prioritize discipline and compliance that is coercive in the form of desired behavior. Parents consider that the child is a responsibility that must be guided so that everything that the parents want that as long as it is considered good for the child is the truth. Therefore, the results showed that parenting patterns play an important role in the formation of self-efficacy in carrying out a physical activity in that case supported by the opinion of Bandura (1997) which explained that there are several other factors that affect self-efficacy in individual parenting patterns, among others; 1]cultural factors, 2]gender, 3]the nature of the task at hand, 4]external incentives, 5]the status or role of the child in the environment of both the family, school and community, 6]self-ability information. Therefore, there needs to be support or motivation from the environment and students can bring up the spirit in him to overcome various problems and challenges faced.

\section{Conclusion}

From the results of the research and discussion above, it can be drawn some conclusions as follows:

1. The pattern of foster care and self-efficacy together significantly affects the physical activity of elementary school students in grade VI, with a score of $\mathrm{F}$ of 3,765 at a significance of 0.005 .

2. Authoritarian parenting patterns significantly influenced the physical activity of students with a beta score of 0.259 at a significance of 0.027 , while the other three foster care patterns had no significant effect.

3. Self-efficacy significantly influenced the physical activity of students with a beta score of 0.458 at a significance of 0.001 .

\section{References}

Bandura, A., Freeman, W. H., \& Lightsey, R. (1999). Self-Efficacy: The Exercise of Control. Journal of Cognitive Psychotherapy. https://doi.org/10.1891/08898391.13.2.158.

Baumrind, D. (1991). Baumrind1991.Pdf. In Sage Journals (Vol. 11, Issue 1, pp. 56-95). https://journals.sagepub.com/doi/pdf/10.1177/0272431691111004.

Burhaein, E. (2017). Aktivitas Fisik Olahraga untuk Pertumbuhan dan Perkembangan Siswa SD. Indonesian Journal of Primary Education. https://doi.org/10.17509/ijpe.v1i1.7497.

Demetriou, Y., \& Höner, O. (2012). Physical activity interventions in the school setting: A systematic review. In Psychology of Sport and Exercise. https://doi.org/10.1016/j.psychsport.2011.11.006.

Dorsch, T.E; Dunn, C.R; Osai, K.V; King, M. Q. (2014). Parent Guide (pp. 1-12).

Erkelenz, N., Kobel, S., Kettner, S., Drenowatz, C., \& Steinacker, J. M. (2014). Parental 
activity as influence on children's BMI percentiles and physical activity. Journal of Sports Science and Medicine, 13(3), 645-650.

Gonzales, P., \& Williams, T. (2009). Highlights From TIMSS 2007. Science.

Hallal, A., Dieny, B., \& Chshiev, M. (2014). Impurity-induced enhancement of perpendicular magnetic anisotropy in $\mathrm{Fe} / \mathrm{MgO}$ tunnel junctions. Physical Review B Condensed Matter and Materials Physics.

Haskell, W. L. (2012). Physical activity by self-report: a brief history and future issues. Journal of Physical Activity \& Health. https://doi.org/10.1123/jpah.9.s1.s5.

Holmes, Robyn M. (2012). The Outdoor Recess Activities of Children at an Urban School Longitudinal and In.

Johns, David P., Ha, Amy S. (1999). Home and recess physical activity of Hong Kong children. Research Quarterly for Exercise and Sport, 70, 3; ProQuest pg. 319.

Katherine T, Amelia M, Jerry R.(1948). Physical Education Methods for Elementary Teachers. USA: Human Kinetics.

Kemenkes RI. (2013). Hasil Riset Kesehatan Dasar Tahun 2013. In Kemenkes RI. https://doi.org/10.1517/13543784.7.5.803.

Kraft, Robert E. (1989).Children at Play: Behavior of Children at Recess. Journal of Physical Education, Recreation \& Dance, 60, 4, ProQuest pg. 21. Laksmi, P. D. (2018).

Kowalski, K., Crocker, P., \& Donen, R. (2004). Physical Activity Questionnaire (Elementary School). The Physical Activity Questionnaire for Older Children (PAQC) and Adolescents (PAQ-A) Manual. https $/ /$ doi.org/10.1249/01.MSS.0000142303.49306.0D.

Laksmi, P. D. (2018). Pengaruh Pola Asuh Orang Tua terhadap Efikasi Diri. Jurnal Penelitian Dan Pengembangan Pendidikan. https://doi.org/10.23887/jppp.v2i1.15342

Laili Deni Kurniawati, I. mardiyanti. (2018). Pola Asuh Orang Tua Mempengaruhi Perkembangan Balita Di Posyandu Arjuna Rw Iv Pos 3 Kelurahan Kemayoran Kecamatan Krembangan Surabaya. Journal of Health Sciences. https://doi.org/10.33086/jhs.v7i1.265.

Leo Marcos, F., Sánchez Miguel, P., Sánchez Oliva, D., Gómez Corrales, F., \& García Calvo, T. (2009). Análisis de las relaciones existentes entre la orientación y el clima motivacional con los comportamientos antisociales en jóvenes deportistas. Revista Iberoamericana de Psicología Del Ejercicio y El Deporte, 4(1), 15-28.

Mahardika, I.M.S (2015) Metodologi Penelitian. Surabaya: Unesa University Press.

Maksum. A (2018) Metodologi Penelitian dalam Olahraga. Surabaya: Unesa University Press.

Maksum. A (2018) Statistik dalam Olahraga. Surabaya: Unesa University Press.

Maksum, A., \& Surabaya, U. N. (2018). Olahraga Bermutu Untuk Semua 1. September.

Marley, A. A. J. (1988). Random utility models with binary tree decomposable rank orders satisfy Tversky's elimination-by-aspects model. Journal of Mathematical Psychology. https://doi.org/10.1016/0022-2496(88)90022-3.

McMahon, E. M., Corcoran, P., O’Regan, G., Keeley, H., Cannon, M., Carli, V., Wasserman, C., Hadlaczky, G., Sarchiapone, M., Apter, A., Balazs, J., Balint, M., Bobes, J., Brunner, R., Cozman, D., Haring, C., Iosue, M., Kaess, M., Kahn, J. P., ... Wasserman, D. (2017). Physical activity in European adolescents and associations with anxiety, depression and well-being. European Child and Adolescent Psychiatry. https://doi.org/10.1007/s00787-016-0875-9.

Ngafifi, M. (2014). Kemajuan Teknologi Dan Pola Hidup Manusia Dalam Perspektif Sosial Budaya. Jurnal Pembangunan Pendidikan: Fondasi Dan Aplikasi. 
https://doi.org/10.21831/jppfa.v2i1.2616.

Sari, N. P. (2018). Hubungan Pola Asuh Orangtua Dan Teman Sebaya Terhadap

Kedisiplinan Belajar Siswa Kelas Iii Sd. Joyful Learining Journal, 7(4), 57-65.

Sujarweni, V. W. (2014). SPSS untuk Penelitian. In SPSS untuk Penelitian.

Santrock, J. W. (2011). Masa Perkembangan Anak: Children. In 2. https://doi.org/10.1016/j.matchemphys.2003.11.036.

Shyny T. Y. (2017). Construction and Validation of PS-FFQ ( Parenting Style Four Factor Questionnaire ). IJEDR, 5(3), 426-437.

Sherwood, I., \& Sherwood, I. (2010). Introduction to Dental Materials. In Materials in Restorative Dentistry. https://doi.org/10.5005/jp/books/11061_1.

Sport, C. (1998). Canadian Sport History. Acadiensis, 28(1), 98. https://doi.org/10.2307/30303241.

Steve Stork dan Stephen W. Sanders. (2008).Physical Education in Early Childhood. The Elementary School Journal, Vol. 108, No. 3 (January 2008), pp. 197-206.

Sugiyono. (2016). Metodologi Penelitian Kuantitatif, Kualitatif, dan R\&D. In CV Alfabeta. https://doi.org/https://doi.org/10.3929/ethz-b-000238666.

Trudeau, F., \& Shephard, R. J. (2008). Physical education, school physical activity, school sports and academic performance. In International Journal of Behavioral Nutrition and Physical Activity. https://doi.org/10.1186/1479-5868-5-10.

Tsai, P. S., Tsai, C. C., \& Hwang, G. H. (2010). Elementary school students' attitudes and self-efficacy of using PDAs in a ubiquitous learning context. Australasian Journal of Educational Technology. https//doi.org/10.14742/ajet.1076.

UU Nomor 20 Tahun 2003. Simtem Pendidikan Nasional. Jakarta : Direktorat Pendidikan Menengah Umum. http:// doi.org/10.1016/j.ypmed.2008.01.025.

Valentin, R. R., \& Hadi, N. U. (2018). Analisis Keyakinan Diri (Self Efficacy) Akademik Dan Pola Asuh Orang Tua Terhadap Kemandirian Belajar Siswa Mata Pelajaran Ekonomi Kelas X Sma Negeri 1 Tulungagung Tahun Pelajaran 2017/2018. Jurnal Pendidikan Ekonomi: Jurnal Ilmiah Ilmu Pendidikan, Ilmu Ekonomi Dan Ilmu Sosial. https://doi.org/10.19184/jpe.v12i1.7749.

Widiyanti, A. A. M. D., \& Marheni, A. (2013). Perbedaan Efikasi Diri Berdasarkan Tipe Pola Asuh Orangtua pada Remaja Tengah di Denpasar. Jurnal Psikologi Udayana. https://doi.org/10.24843/jpu.2013.v01.i01.p17.

WHO. (2015). Physical activity factsheet. From: http//www.who.int/mediacentre /factsheets/fs385/en/.Diakses pada 12 Oktober 2015.

Woolfork, L. (2008). Embodying American slavery in contemporary culture. In Embodying American Slavery in Contemporary Culture. https://doi.org/10.5860/choice.46-5420. 